\title{
The Entrepreneurship Index Scale Building in China
}

\author{
Jian WANG ${ }^{1, a}$, PengWANG $^{2, b}$ \\ ${ }^{1}$ Tianjin University of Finance and Economics \#25 Zhujiang Rd, Hexi District, TianJin, China 300222 \\ ${ }^{2}$ Tianjin University of Finance and Economics \#25 Zhujiang Rd, Hexi District, TianJin, China 300222 \\ awangjian750211@163.com, 'bpzzh322@163.com
}

Keywords: Entrepreneurs,Entrepreneurship,Index.

\begin{abstract}
Entrepreneurship has long been thought to increase employment, creating new markets, promote technological innovation, increase the product or service varieties and improve regional productivity and industrial competitiveness, promote regional economic growth plays an important role.This thesis intends to adopt the davos world economic BBS questionnaires as the basis, building measure scale of Chinese entrepreneur spirit.
\end{abstract}

\section{Introduction}

Peter Drucker in his book innovation and entrepreneurship presents the view of innovation with entrepreneurship. China is in the 21 st century, he thought, from the "industry" to "industry" transition, entrepreneur and entrepreneurship plays a very important role in enterprise development. From the perspective of entrepreneurship, entrepreneur is to determine the main body of enterprise lifeblood, entrepreneurs to the enterprise decisions affect enterprise strategic direction and profit ability, within the enterprise show the personal accomplishment and leadership. Out of the responsibility of the enterprise and influence. In the developed world, entrepreneurship is regarded as to increase economic activity, and an important means of creating employment opportunities, in underdeveloped countries, entrepreneurship is regarded as an effective way to stimulate economic growth. Entrepreneurship is considered to be the main power to promote economic development of a country, one is the enterprise survival and development, is the soul of a enterprise, is the driving force of the enterprise sustainable development. Entrepreneurship is to improve the production efficiency and an important factor in promoting economic growth. With the advancement of China's reform and opening-up process, the Chinese entrepreneur stratum and the formation and development of entrepreneurial economy has become China's economic system reform is an important achievement. Entrepreneurship influence on economic growth, also caused the extensive concern of domestic scholars, the process of China's reform and opening up and economic growth is actually a Chinese entrepreneur class and entrepreneurial spirit to the history of the formation and development process, this was the result of China's economic system reform should be and that, in turn, push the reform forward. Therefore, the research on entrepreneurship index is of great theoretical significance and practical value.

\section{The definition of entrepreneurship}

Entrepreneur spirit is the Chinese translation of English "Entrepreneurship", the intent was engaged in a certain industry, through the set up factories and innovation to achieve its goal, and meet the needs of society.

The definition of entrepreneurship is the logical starting point of the determinants of 
entrepreneurship. Domestic and foreign scholars on the concept of entrepreneurship, there are three main views, can be summarized as "innovation" and "risk-taking" and "market opportunity", they respectively from innovation, risk-taking and the view of market opportunity identification are defined. "Innovation" that entrepreneurship is mainly embodied in the innovative spirit, innovation is the soul of an enterprise, is the decisive factor for enterprise to keep long-term advantage, the innovation of the enterprise can be in the form of organization innovation, a new technology can be used, or is the ability to adapt to environmental changes. For example, an important goal of Schumpeter think entrepreneurship is innovation. Drucker think entrepreneurship is a kind of innovation behavior, can make existing resources more have the ability to create wealth, the essence of which is innovative. Xin-chun li will be understood as a process of entrepreneurship, entrepreneur in completing the process of identifying your own business or the process of innovation; "Risk-taking" that entrepreneurship is the ability of entrepreneurs to take risks and adventurous spirit. Such as Schultz says the entrepreneur spirit is that the ability of entrepreneurs to take risks, adventure spirit and the ability to cope with market imbalances. Officers and soldiers from the perspective of entrepreneur utility that entrepreneurship is the entrepreneur in the process of the pursuit of their own utility maximization of risk-taking, risk preference and behavior, and good faith, professional moral quality;" Market opportunity" emphasizing ability for identifying the market opportunities. Such as Kirzner that entrepreneurship is alertness for has not been realized market opportunities, is the profit-seeking entrepreneurs in the ring with its quality. Venkataraman believes that the core of the entrepreneurial spirit is the recognition of market opportunity and to explore, promote the generation of new products and applications. In addition, yong-dong li from the perspective of China's institutional environment to define entrepreneurship, entrepreneurship is considered in the process of market economy through the operation of the enterprise organization, under the condition of different system formed the entrepreneur consciousness, ideas, such as the ideal activities combined. Although the scholars on the definition of the concept of entrepreneurship is different, but from scholars' research, basic think entrepreneurship should include entrepreneur spirit of entrepreneurship, innovation, risk-taking and adventurous spirit and the spirit of market opportunities.

This paper argues that entrepreneurship refers to the entrepreneurs of the society, economy and down engaged in commerce and industry in the process of operation and management, in the fierce market competition and evolution under the relentless pressure of formation of the psychological state, values, ways of thinking and spiritual quality. Entrepreneurship through entrepreneur's behavior, embodies in the entrepreneur's commodity production and business activities, and it is the basic characteristics of outstanding entrepreneur have together.

\section{The influence factors of entrepreneurship}

For a long time. People on the essence of entrepreneurship and its mechanisms of action happened didn't really understand, to understand the factors involved in entrepreneurship to many factors, this article from the individual level, enterprise level, social level on the influence factor of entrepreneurship research achievements abroad, literature review and comment.

(a) The influence factors of individual level

Individual level entrepreneurship research mainly focused on answer who can become an entrepreneur and why. About "who is the entrepreneur?" Research mainly from the individual's personality, psychological and behavior, and demographic characteristics such as age and gender, education level, work experience and expertise, and family background and social characteristics on to explore the difference between entrepreneurs and ordinary people. Such as McCelland believes 
that entrepreneur's personal characteristics and psychological characteristics, such as success requirements, risk preference, dynamic impact business results.Amar V Bhide that entrepreneurs create promising new businesses need some special quality, have and decisive, entrepreneurial orientation, adapting ability, ability to get resources. And take risks, charisma, management and so on is secondary to the quality. Djankov etc. Through the comparative study between China and Russia's entrepreneurial development found that compared with the entrepreneurs. Demand for successful entrepreneurs more and more adventurous and able to withstand risks, greed and more confident, have a better insight to the system environment. Why a business entrepreneur is answered the question of entrepreneurial motivation. Shane research thought of entrepreneurial motivation by education background, professional background, management experience, social status, age, gender and culture, etc. Entrepreneurial motivation Dubini summarizes the seven factors: achievement, benefits, status, money, escape, freedom and follow the predecessors. Although the entrepreneur is the center of the entrepreneurial activity. The personal qualities is the key to the success of entrepreneurial activity, but the entrepreneur's theory of "nature" severe challenges from the theoretical and empirical.Gartner, points out that psychological traits differences between entrepreneurs is actually much greater than the difference between entrepreneurs and entrepreneur, so there were no typical entrepreneurs psychological traits, there is no need to waste more energy to find the so-called will contribute to the success of entrepreneurial decisions or entrepreneurial psychological quality variables. Entrepreneurs under different cultural background and economic development stage has different psychological characteristics. Therefore, the characteristics of the entrepreneur for different situations is still one of the focus of entrepreneurship research.

(b) The influence factors of enterprise level

With the globalization of economy, market competition, companies from all over the world to company business (Corporate Entrepreneurship. CE) action and strategy, as a company to build and reconstruct the important means of the dynamic competitive advantage, by creating a new resource combination way, developing the company's ability to scope and development opportunities, and ultimately achieve growth process. Company level of entrepreneurship research. From the focus on enterprise internal entrepreneurship research, mainly focused on the analysis of company organization structure and culture influence on entrepreneurship, such as Covin and Slevin think that entrepreneur's innovation ability is embodied in the enterprise for it is in the company organization structure of innovative, pioneering and risk-taking ability Dg].Morris entrepreneur of organization and management style, such as the openness of the organization and its environment. Gerard Keijzers research indicates that the sustainable development of the enterprise culture influence the company's entrepreneurship development.

Existing research from the organizational culture, organizational strategy, organizational structure, organization and leadership, entrepreneurship, innovation incentive mechanism and management research on the influence of corporate performance, but the effect of the corporate entrepreneurship is affected by the organizational learning capability, future research may consider organizational learning in the performance of corporate entrepreneurship and corporate entrepreneurship.

(c) The influence of social factors

With the rapid development of entrepreneurship around the world and great contributions to economic growth and entrepreneurship research also is able to in the broader environment, economy, religion, politics, law and education, etc.), and led to many studies cross-regional, across different cultures and countries. The state and society levels of research focused on how the entrepreneurs found in the changing environment and make use of opportunities, mainly inspects 
the macro system and cultural environment for entrepreneurship. Such as Coasel and Nonff think reasonable system arrangement provides incentives for entrepreneurial activity. Reynolds, such as the global entrepreneurship monitor researchers developed 9 framework environment influence factors of entrepreneurial opportunity and ability; Blanehflower emphasize the different characteristics of culture and system; Minniti and vesque study found that deregulation has a promoting effect on entrepreneurship development; LuthansL and when analyzed the political and economic environment, especially the national politics, economy and the influence of various institutional arrangements for entrepreneurship; LumPkin and Dess highlights the industry changes in the environment to stimulate the role of entrepreneurship; Peter - son Lee and comparative analysis of the different cultural environment on the influence of entrepreneurship, and Baumol, emphasizes the institutional arrangements affect the type and amount of entrepreneurship. Most of existing studies considered separately formal system and informal system influence on entrepreneurship, entrepreneurial activity in the real decision at the same time is affected by the formal system and informal system together, therefore, need to consider the formal system and informal system interaction effects on entrepreneurship.

\section{The construction of entrepreneurship index}

According to the conceptual model of the determinants of entrepreneurship, and combined with the content of the questionnaire, puts forward the technology, competition, innovation and operations, personnel, five latent variables according to the elaboration of relevant research literature and reports, such as table 1 observed variables, and thus the design scale of item.

Table 1 The influence factors of entrepreneurship and index selection

\begin{tabular}{|c|c|}
\hline Factor & Measure index \\
\hline \multirow{7}{*}{ Technology } & Get the latest technology \\
\hline & Get the degree of the new technology from foreign \\
\hline & $\begin{array}{l}\text { Companies use information and communications technology to } \\
\text { create new business models }\end{array}$ \\
\hline & $\begin{array}{l}\text { Companies use new technologies and other enterprises to carry out } \\
\text { trading activities }\end{array}$ \\
\hline & Companies use the Internet for the level of customer service \\
\hline & $\begin{array}{l}\text { Enterprise use of information and communication technologies to } \\
\text { create a new organization mode }\end{array}$ \\
\hline & The acceptance of new technology \\
\hline \multirow{6}{*}{ Competition } & Fierce competition \\
\hline & The number of suppliers \\
\hline & The supplier's quality \\
\hline & Degree of monopoly enterprises \\
\hline & Higatuhly mre and depth of the development of the industrial cluster \\
\hline & $\begin{array}{l}\text { The extent of the declaration and registration to engage in economic } \\
\text { activities }\end{array}$ \\
\hline \multirow{3}{*}{ Innovation } & $\begin{array}{l}\text { The degree of competitiveness comes from the unique products and } \\
\text { processes }\end{array}$ \\
\hline & $\begin{array}{l}\text { The participation degree of the enterprise in the value chain as a } \\
\text { whole }\end{array}$ \\
\hline & Degree of enterprise for its products in the market circulation of the \\
\hline
\end{tabular}




\begin{tabular}{|c|c|}
\hline & control \\
\hline & Enterprise production process maturity \\
\hline & Enterprise's innovation ability \\
\hline & Business investment in research and development (R\&D) \\
\hline & Encourage employees to innovation \\
\hline & $\begin{array}{l}\text { The enterprise will be concepts into the possibility of new products, } \\
\text { services and business models }\end{array}$ \\
\hline & $\begin{array}{l}\text { Companies to accept high wind, the extent of the disruptive business } \\
\text { point of view }\end{array}$ \\
\hline & For enterprise innovation risk acceptance \\
\hline \multirow{6}{*}{ Operation } & Executives in the professional managers preferred choice \\
\hline & At the top to the lower willingness to delegate \\
\hline & $\begin{array}{l}\text { The degree to which investors and the board of directors is } \\
\text { responsible for the management }\end{array}$ \\
\hline & Enterprise's attitude to customers \\
\hline & Enterprises to product and service marketing effect \\
\hline & Create international brand \\
\hline \multirow{9}{*}{ Talents } & High quality professional training services \\
\hline & Companies use the Internet to carry out the learning activities \\
\hline & To the difficulty of the enterprise find the employees \\
\hline & The relevance of the company worker pay and labor productivity \\
\hline & Enterprise investment in employee training and development \\
\hline & The degree of retaining talent \\
\hline & The extent of attracting overseas talents \\
\hline & $\begin{array}{l}\text { Enterprises in the aspect of promotion the equality of men and } \\
\text { women }\end{array}$ \\
\hline & Enterprise and employee relations of cooperation \\
\hline
\end{tabular}

This paper draws on the most commonly used Likert scale method, Likert scale (Likert scale) is commonly used in the rating aggregation type scale of a project is made up of the concept of are the same way to score, alone or individual items is meaningless.It is by the American social psychologist likert in 1932 based on the original sum scale improvement.

Research chooses Likert 7 subscales, namely one to seven, seven representatives from weak to strong 1 represents "strongly disagree" 2 "is not agree," three representatives "not agree", 4 represents the "neutral", 5 representative "agree", 6 on behalf of the "agree", 7 "strongly agree".According to each entrepreneur's answer to remember for 1, 2, 3, 4, 5, 6, 7 points, each respondent's attitude score is his answer to each question by scores of aggregation, the total score is that his attitude on the scale of strength or her different states.Seven subscales was chosen as higher precision and can refine the entrepreneur's attitude to various problems, accurately distinguish the difference of every entrepreneur, make the results of the questionnaire analysis more credibility.

\section{Summary}

Although a lot of research literature on entrepreneurship, but more is the study of factors affecting entrepreneur, domestic to build entrepreneurship index and measure of quantitative research has not yet appeared, this paper build a metric system, for the structural equation model is 
constructed to analyze the relationship between the factors affecting the entrepreneurship, from regional and industry differentiation analysis was carried out on the index of the entrepreneurial spirit, to create the necessary condition, has carried on the exploratory research.

\section{References}

[1] Wei-pingWei. Based on structural equation model of entrepreneurship and corporate performance relationship research [D]. Tianjin university. 2008

[2] Lei Zhang. Entrepreneurship and economic growth of China, based on data from 1994-2009, China [D]. An-hui university of technology

[3] zhong-wei Chen, yu-li zhang. The development of the theory of entrepreneurship context analysis [J], Chinese and foreign entrepreneurs, 2007 (10): 21 to 25.

[4] Xiao-jingDing . Under the perspective of macro environment of entrepreneurship cultivation mechanism [J]. Social science front, 2008 (12) : 252-253.

[5]Gui-shengFu, Jin-yong Guo. Entrepreneurship and economic growth [J]. Journal of jiangxi agricultural university (social science edition), 2004 (3) : 82-84.

[6] Bo Gao. Culture, cultural capital and the regional difference of entrepreneurship [J]. Journal of nanjing university (philosophy, humanities and social sciences), 2007 (5) : 74-80.

[7] Tie-mei Gao, Shu-longKang. Foreign direct investment in dynamic analysis of the impact of China's economy [J]. Journal of world economy, 2006 (4) : 22 to 30.

[8] Yu-ping He. Entrepreneurship and economic growth, China - based on c-d production function of the empirical study [J]. Journal of contemporary finance and economics, 2006 (7) : 95-100.J.G

[9]Covin-Slevin,-D.P.S,trategicmanagementofsmallfirmsinhostileandbenignenvironments

$[\mathrm{J}]$.

Journal of StrategicManagement. 1989 (10) : 75-87

[10]Jun-xiuLiu. The influence of entrepreneurship on economic growth of zhejiang research [D]. Zhejiang university of technology. 2012

[11] Xue-yin Ou.Entrepreneurship theory and empirical study of the impact of economic development [M]. Hu-nan university. 2009

[12] Chuan-yi Lu,Zi-nai Li. Entrepreneurship and economic growth theory [J]. Journal of tsinghua university (philosophy and social sciences

Edition), 2000, (3) : 42-49.

[13] Xing-qi Lu,Qin Wang .Entrepreneurial spirit and contemporary economic growth [J]. Journal of business research, 2006 (2) : 18 to 21.

[14] Chun-rong Liu. Introduce the entrepreneurial thinking about the theory of the economic growth [J]. Journal of shandong economy, 2005, 11 (6) : 68-72.

[15]Audretsch,D.B.,Thurik,A.R.LinkingEntrepreneurshiptoGrowth[R].OECDScience,Technologya ndIndustry.OECDWorkingPapers, 2001

[16]Audretsch,D.B.,Fritsch,M.GrowthRegimesOverTimeandSpace.RegionalStudies[J].2002(36):11 3-124.

[17]Carre,M.,A.vanStel,R.ThurikandS.Wennekers.EconomicDevelopmentand

BusinessOwnership:AnAnalysisUsingDataof23OECDCountriesinthePeriod1976-1996[J].SmallBusi nessEconomics,2002(19).

[18]HolcombeR.G.EntrepreneurshipandEconomicGrowth[J].TheQuarterlyJournalofAustrianEcono mics, 1998(2):45-62.

[19]Kirzner,IsraelM.CompetitionandEntrepreneurship[M].Chicago:UniversityofChicagoPress, 1973. 